\section{Commentary: Autograft remodeling after the Ross procedure. Keep a stiff upper lip}

\author{
Marvin D. Atkins, MD, and Michael J. Reardon, MD
}

Donald Ross devised and first performed the Ross procedure in 1962, when surgeons had no prosthetic valves to turn to and he was looking for available and reasonable valve substitutes. ${ }^{1}$ It is the only aortic valve-replacement procedure that can provide a viable aortic valve that can grow with young patients. It is also the aortic valve substitute that most closely matches normal hemodynamic flow. Despite these potential advantages, the Ross procedure has not been widely adopted due to the technical skill required to do the procedure well and has been largely confined to reference centers and surgeons with a specific interest in this approach. Even in those centers and in the hands of experienced Ross surgeons, questions remain. One observation has been the potential for more dilatation when a Ross procedure is done for aortic insufficiency (AI) versus aortic stenosis (AS), as has been suggested in previous studies. ${ }^{2}$ A knowledge gap exists as to the potential reason for this observation and if it related to a genetic tissue difference between patients with $\mathrm{AS}$ and $\mathrm{AI}$, a procedural reason, or a response to poor blood pressure (BP) control in the initial postoperative period during remodeling of the autograft. Multiple surgical techniques (subcoronary reimplantation, annular and sinotubular junction stabilization, and the inclusion technique) have been lumped together under the heading of a Ross operation, further clouding direct comparisons between groups.

In this issue of the Journal, the Montreal group looks for the answer to these questions in their extensive experience with the Ross procedure. ${ }^{3}$ Their aim in this study was to compare the biomechanical and morphologic remodeling at 1 year between cases done for AS or AI with cardiac

\footnotetext{
From the Department of Cardiovascular Surgery, Houston Methodist Hospital, Houston, Tex.

Disclosures: Authors have nothing to disclose with regard to commercial support.

Received for publication March 26, 2020; revisions received March 26, 2020; accepted for publication March 26, 2020; available ahead of print April 8, 2020.

Address for reprints: Michael J. Reardon, MD, Department of Cardiovascular Surgery, Houston Methodist Hospital, Houston, TX 77030 (E-mail: mreardon@ houstonmethodist.org).

J Thorac Cardiovasc Surg 2022;163:588-9

$0022-5223 / \$ 36.00$

Copyright (c) 2020 by The American Association for Thoracic Surgery

https://doi.org/10.1016/j.jtcvs.2020.03.075
}

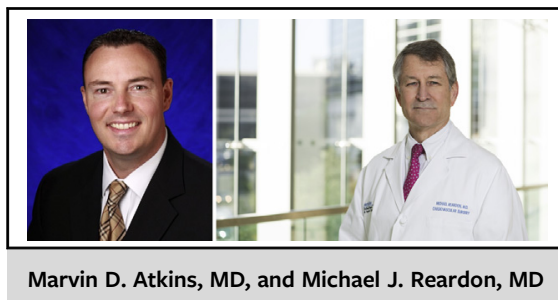

CENTRAL MESSAGE

Ross autografts have similar morphologic and biomechanical features for both aortic stenosis and insufficiency, given strict early blood pressure control and the authors' implantation techniques.

magnetic resonance (CMR) imaging. Over the period from 2011 to 2016, their group did 210 Ross procedures. Of this group, 86 patients had both a pre- and 1-year post-CMR to use for comparison. The CMR data were inadequate for use in 15 patients, leaving 71 for analysis (41 AS and 30 AI). They also had 9 healthy volunteers that were used as controls. They describe their standardized surgical technique that is tailored to help avoid dilatation well. This included placing the autograft within the left ventricular outflow tract so that the native fibrous annulus would provide support. In patients with an annulus $>27 \mathrm{~mm}$ or with a $>2$-mm discrepancy with the autograft, the authors used an external aortic ring annuloplasty. Distally, the anastomosis was done within 1 to $2 \mathrm{~mm}$ of the sinotubular junction to avoid leaving excessive autograft tissue exposed to systemic pressures. If there was a distal mismatch between the autograft and the native aorta, a short, 26 or $28 \mathrm{~mm}$, Dacron graft was interposed. Finally, they placed the thinner left facing autograft sinus posteriorly facing the left coronary so that mediastinal tissues could provide support. Postoperatively, they pursued aggressive $\mathrm{BP}$ management to keep the systolic $\mathrm{BP}<115 \mathrm{~mm} \mathrm{Hg}$ with beta blocker as frontline therapy for impulse control. They found that the Ross graft in both AS and AI was slightly larger and stiffer than the normal control and that both the AS and AI Ross autografts and normal control patients had homogenous geometry.

These findings suggested to the authors that using their tailored implantation technique and aggressive BP control led to no differences between autografts done for AS or AI, and we would agree that both are important. Surgical technique is usually in the forefront of the surgeon's 
thoughts but postoperative pharmacologic control of BP should command more attention during the remodeling phase as the pulmonary autograft adjusts to systemic pressures. We view these findings as comforting but see several areas of continued concerns for Ross surgeons. The first is the increased stiffness of the autografts in both patients with AS and AI. In the authors' tailored technique, it appears that there is not a biomechanical difference in the early (1-year) results following the Ross procedure between patients with AS and AI. In addition, the authors found that the interposition of a Dacron graft distally further increased stiffness, and note that they have become less aggressive in using these grafts when possible. The long-term implications of autograft stiffness are unclear. Further imaging studies and longer-term clinical follow-up will help elucidate a mechanism associated with late Ross autograft failure. The present study shed light on the fact that it may not be due to an early biomechanical difference between the 2 groups. Finally, we must recognize that this study represents a subset of their Ross procedures and that this subset is further divided into those willing and able to return at 1 year for a follow-up CMR. This may represent a group especially dedicated to following up with their health and thus more aggressive in following their prescribed BP control. It remains unknown if less aggressive BP control would have exposed differences between AS and AI.

We congratulate the authors both on their excellent work and long-term dedication to improving the Ross procedure. The authors have taken a procedure born in London and maintained a steady and determined approach to solving the problems they faced - a stiff upper lip—or perhaps for our Montreal friends-essayer de garder le sourire. Stay calm and carry on with your excellent work.

\section{References}

1. Ross DN. Homograft replacement of the aortic valve. Lancet. 1962;2:487.

2. David TE, David C, Woo A, Manlhiot C. The Ross procedure: outcomes at 20 years. J Thorac Cardiovasc Surg. 2014;147:85-93.

3. Lenoir M, Emmott A, Bouhout I, Poirier N, Tousch M, El-Hamamsy I, et al. Autograft remodeling after the Ross procedure by cardiovascular magnetic resonance imaging: aortic stenosis versus insufficiency. J Thorac Cardiovasc Surg. 2022;163:578-87.e1.
See Article page 578

\section{Commentary: There is no aortic root remodeling after aortic conduit surgery}

\section{Ari A. Mennander, MD, PhD}

A patient with a diseased aortic valve does not usually seek superb technical achievement. The aortic valve or conduit operation using prosthesis are reliable options; at least there is no risk for pulmonary graft or homograft root dilatation.

The Ross procedure is an innovative option to replace the diseased aortic valve using the native pulmonary valve as a graft $^{1}$; the main aim is to avoid life-long anticoagulation

\footnotetext{
From Tampere University Heart Hospital and Tampere University, Tampere, Finland. Disclosures: The author reported no conflicts of interest.

The Journal policy requires editors and reviewers to disclose conflicts of interest and to decline handling or reviewing manuscripts for which they may have a conflict of interest. The editors and reviewers of this article have no conflicts of interest.

Received for publication April 3, 2020; revisions received April 3, 2020; accepted for publication April 3, 2020; available ahead of print April 18, 2020.

Address for reprints: Ari A. Mennander, MD, PhD, Tampere University Heart Hospital, SDSKIR, PL 2000, Tampere, Finland (E-mail: ari.mennander@sydansairaala. fi).

J Thorac Cardiovasc Surg 2022;163:589-90

$0022-5223 / \$ 36.00$

Copyright (C) 2020 by The American Association for Thoracic Surgery

https://doi.org/10.1016/j.jtcvs.2020.04.017
}

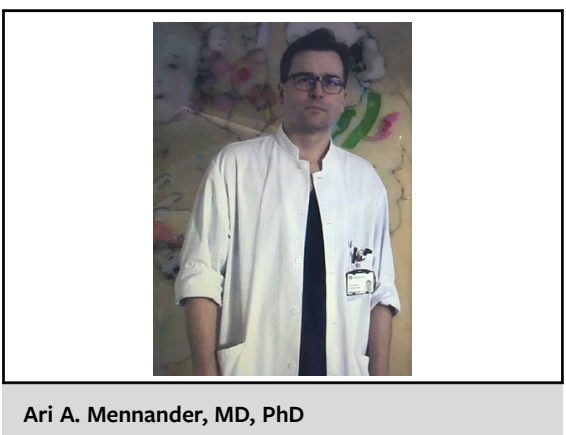

CENTRAL MESSAGE

Possible aortic and pulmonary

root tissue compatibility may

hint that many patients with

aortic valve disease need not

have their aortic root resected.

therapy. ${ }^{2}$ Would the dilated aortic valve annulus and aortic root after aortic valve insufficiency signify imminent dilation of the corresponding parts of the pulmonary root graft after the Ross procedure ${ }^{3}$ The study by Lenoir and colleagues ${ }^{4}$ investigated whether aortic insufficiency may be controlled 